\section{Beijing+20: Some Musings}

Prof. Archana Sharma ${ }^{\dagger}$

This year the Beijing Platform for Action turns 20. The Beijing Platform for Action constitutes a global framework for realising gender equality and the empowerment of women, and it 'envisioned gender equality in all dimensions of life'. Contrary to expectations, even after so many years of concerted action, no country in the world could completely close the gender gap. According to the latest report of the World Economic Forum, 'it will take 81 years to close the gender gap worldwide if the progress continues at the current rate.' The SecretaryGeneral of the United Nations, in the Report of the Economic and the Social Council on Review and Appraisal of the Implementation of the Beijing Declaration and Platform for Action and the Outcomes of the Twenty-third Special Session of the General Assembly has observed that in the post-Beijing period, there 'has been limited progress towards gender equality' ... while considerable progress has been made on certain aspects like education, employment, removal of discriminatory laws, etc., the 'overall progress, has been unacceptably slow, with stagnation and even regression in some contexts'. Realising the urgency of the situation, the United Nations has put renewed emphasis on the need to identify the challenges hindering gender equality. The 'UN Women', United Nations entity for Gender Equality and Empowerment of Women, launched the strategy Planet 50-50 by 2030: Step It Up for Gender Equality on the International Women's Day 2015. This has 'come at a critical moment in time as a new development agenda is taking shape to replace the Millennium Development Goals'.

\footnotetext{
${ }^{\dagger}$ Professor and Former Head, Department of Economics Formerly Director, Women's Studies Research Centre and founder Head, Department of Women's Studies, Gauhati University, Guwahati-781014,
}

Email: archasharma@gmail.com

(C)2015 Sharma. This is an Open Access article distributed under the terms of the Creative Commons Attribution License (http://creativecommons.org/licenses/by/2.0), which permits unrestricted use, distribution, and reproduction in any medium, provided the original work is properly cited.
Although gender equality does not end up only in catching up with men, inequalities do reflect the inequities faced by women in different aspects of life. To take the case of India, statistics reveal that women in India still face different types of inequalities, which are interlinked with one form of inequality leading to another. The underlying causes of such inequalities could be found in the traditional patriarchal norms and practices.

The worst form of subordination and oppression that Indian women are subjected to is manifest in the incidents of spousal violence, sexual harassment at workplace, witch hunting, trafficking and many other forms of crime and violence against women. Of late, there has been a spurt of such crimes. Even in those areas where until recently such incidents were never heard of, crimes against women have become a common feature. Sheer neglect of the girl child and the women becomes evident from the prevalence of son preference, female foeticide, high maternal mortality and infant mortality rates.

Another visible form of discrimination could be perceived in the labour market. The female work participation rate is very low in India. In 1971, it was only 12.11 percent against 52.61 percent male work participation rate. It increased by 7.56 percent between 1971 and 1981 but by only 2.6 percent from 1981 to 1991. It was below 25 percent in 1991, when India resorted to economic reforms.

It was expected that the opening-up of the economy would improve the work participation rate of women. The argument was based on the assumption that economic reforms will lead to growth and an expansion of the labour market. In the market-oriented economy, women's unpaid activities will also find a market. However, reality turned otherwise. The country did experience a higher growth rate but the upswing was neither even all throughout nor was accompanied by an 
expansion of the job market-it was more a jobless growth. The female work participation rate had an upward trend in the first decade of reforms with an increase of 3.36 percent between 1991 and 2001 but thereafter had a downward trend. On the other hand, male work-participation rate continued the upward trend although the total male work participation rate was only a few points above 50 percent.

Women workers have very little space in the organised sector. Employing more than 90 percent of women workers, the unorganised sector is the major source of livelihood for women. Within the sector, more women could be seen in the low-paid activities. Large chunks of women working in the organised sector also are engaged in the informal and casual type of jobs. Sections of women workers earn a livelihood through different types of activities outside the formal job market. These women workers, in spite of being deprived of economic and social security, typical of workers in the unorganised sector and unorganised workers, not only contribute to their household income but also add a substantial sum to the State exchequer through indirect taxes.

Inequalities in the labour market is a fall-out of gender inequalities within the household and results in gender inequalities in the other sectors. If the inequalities in the labour market persist, the country will not be able to reap the fullest benefit of the demographic dividend.

Considering the fact that India has been recognised as an emerging economic giant, one of the most brilliant performers among the BRICS countries, the prevailing situation of women is quite paradoxical. It is even more perplexing because India had given due space to the principle of gender equality in the Indian Constitution. While the Preamble, Fundamental Rights, Fundamental Duties and Directive Principles of State Policy laid the foundation, the 73rd and the 74th Constitutional Amendment Acts had paved the way for women's participation in Panchayats and in the urban local bodies thereby, enabling them to be active participants in the development process. A number of legislations have been enacted for the empowerment of women. Women's issues have been addressed also through the planning mechanism. India has also ratified various international conventions and human rights instruments committing to secure equal rights of women. It may be noted that most of these initiatives preceded the Beijing Declaration.

The paradox becomes all the more complicated when it is noticed that these commitments and efforts have paid dividends, but only to a privileged few, creating a great divide between a group of liberated women and the other-the majority-struggling for a livelihood, reeling under violence and oppression.

A truly gender-just society expects that these differences exist no more. Let gender equality be not just a target, not just numbers, let there be choices and opportunities for both men and women. If the target is 'Planet $50-50$ by 2030', women must have the opportunity to participate in decision making at every step for determining the future of the planet. Both in the government and the non-government sector, women are conspicuous by their absence in decision-making positions. A gender sensitive planning mechanism and an equally sensitive implementation process would go a long way in achieving gender equality. It is high time to resort to gender planning in true spirit or else gender equality will remain a distant dream and- 'equality delayed is equality denied'. 